\title{
First Study of Poly(3-Methylene-2-Pyrrolidone) as a Kinetic Hydrate Inhibitor
}

Abrahamsen, Eirin; Heyns, Ingrid Marié ; von Solms, Nicolas; Pfukwa, Rueben; Klumperman, Bert; Kelland, Malcolm A.

\section{Published in:}

Energy \& Fuels

Link to article, DOI:

10.1021/acs.energyfuels.7b03006

Publication date:

2017

Document Version

Peer reviewed version

Link back to DTU Orbit

Citation $(A P A)$ :

Abrahamsen, E., Heyns, I. M., von Solms, N., Pfukwa, R., Klumperman, B., \& Kelland, M. A. (2017). First Study of Poly(3-Methylene-2-Pyrrolidone) as a Kinetic Hydrate Inhibitor. Energy \& Fuels, 31(12), 13572-13577. https://doi.org/10.1021/acs.energyfuels.7b03006

\section{General rights}

Copyright and moral rights for the publications made accessible in the public portal are retained by the authors and/or other copyright owners and it is a condition of accessing publications that users recognise and abide by the legal requirements associated with these rights.

- Users may download and print one copy of any publication from the public portal for the purpose of private study or research.

- You may not further distribute the material or use it for any profit-making activity or commercial gain

- You may freely distribute the URL identifying the publication in the public portal 


\section{energy fuels:}

Subscriber access provided by DTU Library

\section{Article}

FIRST STUDY OF POLY(3-METHYLENE-2PYRROLIDONE) AS A KINETIC HYDRATE INHIBITOR

Eirin Abrahamsen, Ingrid Marie Heyns, Nicolas von Solms, Rueben Pfukwa, Bert Klumperman, and Malcolm A. Kelland

Energy Fuels, Just Accepted Manuscript • DOI: 10.1021/acs.energyfuels.7b03006 • Publication Date (Web): 15 Nov 2017

Downloaded from http://pubs.acs.org on November 20, 2017

\section{Just Accepted}

"Just Accepted" manuscripts have been peer-reviewed and accepted for publication. They are posted online prior to technical editing, formatting for publication and author proofing. The American Chemical Society provides "Just Accepted" as a free service to the research community to expedite the dissemination of scientific material as soon as possible after acceptance. "Just Accepted" manuscripts appear in full in PDF format accompanied by an HTML abstract. "Just Accepted" manuscripts have been fully peer reviewed, but should not be considered the official version of record. They are accessible to all readers and citable by the Digital Object Identifier (DOI®). "Just Accepted" is an optional service offered to authors. Therefore, the "Just Accepted" Web site may not include all articles that will be published in the journal. After a manuscript is technically edited and formatted, it will be removed from the "Just Accepted" Web site and published as an ASAP article. Note that technical editing may introduce minor changes to the manuscript text and/or graphics which could affect content, and all legal disclaimers and ethical guidelines that apply to the journal pertain. ACS cannot be held responsible for errors or consequences arising from the use of information contained in these "Just Accepted" manuscripts. 


\title{
FIRST STUDY OF POLY(3-METHYLENE-2-PYRROLIDONE) AS
} A KINETIC HYDRATE INHIBITOR

Eirin Abrahamsen ${ }^{*}$, Ingrid Marié Heyns ${ }^{\dagger}$, Nicolas von Solms ${ }^{\S}$, Rueben Pfukwa ${ }^{\dagger}$, Bert Klumperman $^{\dagger}$ and Malcolm A. Kelland ${ }^{\ddagger}$

$¥$ Department of Mathematics and Natural Sciences, Faculty of Science and Technology, University of Stavanger, N-4036 Stavanger, Norway

$\S$ Center for Energy Resources Engineering, Department of Chemical and Biochemical Engineering, Technical University of Denmark, Søltoft Plads, Building 229, DK-2800 Kgs., Lyngby, Denmark

${ }^{\dagger}$ Department of Chemistry and Polymer Science, Stellenbosch University, Private Bag X1, Matieland 7602, South Africa

* Corresponding author: eirin.abrahamsen@uis.no

\begin{abstract}
Formation of gas hydrates is a problem in the petroleum industry where the gas hydrates can cause blockage of the flowlines. Kinetic hydrate inhibitors (KHIs) are water-soluble polymers, sometimes used in combination synergistically or with non-polymeric synergists, that are used to prevent gas hydrate blockages. They have been used in the field successfully since 1995. In this paper, we present the first KHI results for the polymer, poly(3-methylene-
\end{abstract}


2-pyrrolidone) ( $\mathrm{P}(3 \mathrm{M} 2 \mathrm{P}))$, which is structurally similar to poly $(N$-vinylpyrrolidone) (PVP), one of the first KHIs to be discovered. 3M2P polymers with different molecular weights (5500 and $2500 \mathrm{~g} / \mathrm{mole})$ and at different concentrations (2500, 5000 and $7500 \mathrm{ppm})$ were investigated for their KHI performance on SII hydrates in high-pressure rocking cells. We also investigated the synergistic effect of $\mathrm{P}(3 \mathrm{M} 2 \mathrm{P})$ with $n$-butyl glycol ether (BGE), a known synergist for some KHI polymers.

At the lower concentrations, $\mathrm{P}(3 \mathrm{M} 2 \mathrm{P})$ gives a similar performance to $\mathrm{PVP}\left(M_{w}=8000-9000\right.$ $\mathrm{g} /$ mole). However, PVP outperforms both samples of $\mathrm{P}(3 \mathrm{M} 2 \mathrm{P})$ at $7500 \mathrm{ppm}$, with and without BGE. We suggest that the reasons for the performance level of $\mathrm{P}(3 \mathrm{M} 2 \mathrm{P})$ are related to greater resonance stabilization of the amide group in $\mathrm{P}(3 \mathrm{M} 2 \mathrm{P})$ compared to $\mathrm{PVP}$. Also, the pyrrolidone ring of the PVP repeat unit has a larger hydrophobic sequence of three methylene units compared to the two methylene units in the pyrrolidone ring of $\mathrm{P}(3 \mathrm{M} 2 \mathrm{P})$. This relates well to previous studies where larger hydrophobic groups are preferable in KHI polymers as long as they are water-soluble at hydrate-forming temperatures.

\section{INTRODUCTION}

Gas hydrates formed from produced water and natural gas can potentially block production flowlines in the upstream petroleum industry. ${ }^{1-3}$ Increased pressure and low temperatures are stable conditions for gas hydrate formation as long as there is free water and smaller hydrocarbons present. Typical hydrocarbons present in natural gas include methane, propane, iso-butane as well as carbon dioxide and hydrogen sulfide. ${ }^{4-6}$

Kinetic hydrate inhibitors (KHIs) are a class of low dosage hydrate inhibitor (LDHI) which have been used to mitigate against hydrate plug formation for over 2 decades. ${ }^{1,7,8}$ 
KHIs delay gas hydrate nucleation and/or crystal growth within the thermodynamically stable hydrate region. The mechanisms for inhibition are not fully understood, but include both nucleation and crystal growth inhibition. ${ }^{9-11}$ All gas hydrate KHIs are oligomers or polymers with multiple active functional groups. Non-polymeric molecules can be added to the polymers to boost the performance synergistically, but alone these molecules are poor KHIs for gas hydrate inhibition. ${ }^{12,13}$

One of the very first KHI polymers discovered was poly( $N$-vinylpyrrolidone) (PVP) (Figure 1). ${ }^{14,15}$ Not only was it found that this polymer delayed hydrate formation, but when the first crystals formed they did not immediately agglomerate. ${ }^{16-18}$ However, as water conversion to hydrate progressed a plug was formed as with all KHIs when applied outside their performance window. The subcooling to which you can prevent hydrate formation for a certain time interval is generally used as a measure of the KHI performance. The subcooling to which PVP delays gas hydrate formation is fairly low compared to the best KHI polymers on the market today such as those based on $\mathrm{N}$-vinylcaprolactam (VCap), $\mathrm{N}$-isopropylmethacrylamide or poly(ester amide)s. However, PVP has a high cloud and deposition point, compared to some KHI polymers, even in high salinity waters and is therefore used in some KHI formulations. ${ }^{19}$ The cloud point temperature $\left(T_{C l}\right)$ is important for the production and transport of oil and gas as the production fluids are often very hot. However, will cool down if there is a shut-in of the flow lines, or as the transport lines stretch over longer distances, for example across the seabed offshore. ${ }^{1,20}$ 

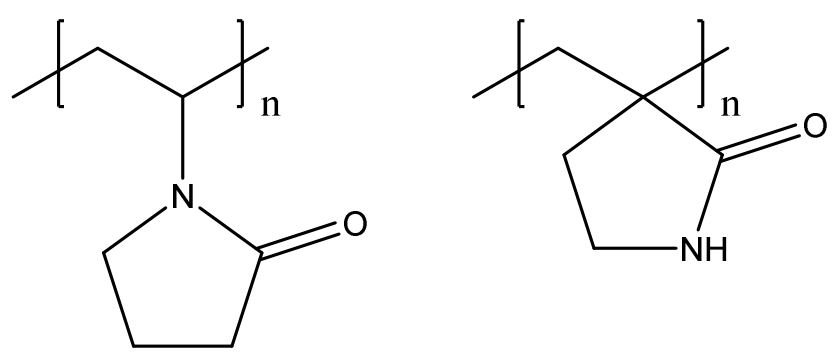

Figure 1. Poly( $N$-vinyl pyrrolidone) (left) and poly(3-methylene-2-pyrrolidone) (right).

Sometimes the solvent used in KHI formulations is a synergist in its own right. $n$-butyl glycol ether (or 2-butoxyethanol, BGE) is a known synergist used with commercial KHIs such as poly( $N$-vinylcaprolactam) (PVCap), PVP and copolymers of VCap and $N$-vinyl pyrrolidone (VP). ${ }^{12,21,22}$ BGE has negligible KHI effect by itself at typical KHI doses (< 1 wt.\%), like other small alcohols and glycols. ${ }^{23}$

Recently, a related class of polymer has been developed based on the 3-methylene-2pyrrolidone (3M2P) monomer (Figure 1). ${ }^{24}$ As with PVP, the 3M2P homopolymer, poly(3methylene-2-pyrrolidone) $\mathrm{P}(3 \mathrm{M} 2 \mathrm{P})$, also contains a pendant pyrrolidone ring, however the polyvinyl backbone originates from the conjugated methylene group in the alpha position of the pyrrolidone. In addition, the first reports of this polymer suggest a high cloud point, which as previously discussed is a useful property for injection into hot fluids at the wellhead.

This report describes the first KHI study with $\mathrm{P}(3 \mathrm{M} 2 \mathrm{P})$ and compares the results to PVP. The synergism of these polymers with added BGE was also investigated. 


\section{EXPERIMENTAL METHODS}

\section{Chemicals and Polymer Synthesis}

PVCap was obtained from BASF as Luvicap EG HM, a 41 wt.\% solution of polymer in monoethylene glycol (MEG) with a molecular weight of 7000-12000 g/mole. PVP was obtained from Ashland Chemical as PVP K-15, with a molecular weight of approximately 8000-9000 g/mole and as a pure powder. All chemicals for synthesis and BGE for the KHI studies were purchased from VWR and Sigma-Aldrich. All solvents were used without further purification. ${ }^{1} \mathrm{H}$ and ${ }^{13} \mathrm{C}$ NMR spectra were obtained with a Varian VXR-Unity $(300 \mathrm{MHz})$ spectrometer. Mass Spectrometry (LC-MS) was obtained with a Waters Synapt G2 with Electron Spray Ionization (ESI) in the positive mode. Synthesis of 3M2P was performed by $^{24,25}$ the crossed Claisen condensation of $N$-boc-2-pyrrolidone and diethyl oxalate in a basic medium, followed by $\beta$-elimination with paraformaldehyde, yielding a methylene moiety at the alpha position of the ring. Subsequently the $N$-boc-protecting group was removed with trifluoroacetic acid. 3M2P monomer: ${ }^{1} \mathrm{H}$ NMR $\left(300 \mathrm{MHz}, \mathrm{CDCl}_{3}-\mathrm{d}_{1}\right) \delta: 7.39$ (bs, $\left.1 \mathrm{H},-\mathrm{N} \underline{\mathrm{H}}\right)$, $6.06\left(\mathrm{t}, \mathrm{J}=2.8 \mathrm{~Hz}, 1 \mathrm{H},=\mathrm{C}_{\mathrm{H}}\right), 5.47\left(\mathrm{td}, \mathrm{J}=2.4,0.7 \mathrm{~Hz}, 1 \mathrm{H},=\underline{\mathrm{C}}_{\mathrm{a}}\right), 3.54-3.48(\mathrm{~m}, 2 \mathrm{H},-$ $\left.\mathrm{C}_{2}-\mathrm{NH}\right), 2.93-2.85\left(\mathrm{~m}, 2 \mathrm{H},-\mathrm{CH}_{\underline{2}}-\mathrm{C}=\right) .{ }^{13} \mathrm{C} \mathrm{NMR}\left(300 \mathrm{MHz}, \mathrm{DMSO}-\mathrm{d}_{6}\right) \delta: 175.45,141.62$, 114.47, 38.90, 26.32. MS (ESI): $\mathrm{m} / \mathrm{z}=98.1$ (calculated: 98.06 for $[\mathrm{M}+\mathrm{H}]^{+}$). Polymerization of $3 \mathrm{M} 2 \mathrm{P}$ was successfully carried out as described earlier ${ }^{24}$ by the use of a reversible deactivation radical polymerization technique (RDRP), namely reversible addition fragmentation (chain) transfer (RAFT) polymerization (Figure 2). The $M_{n}$ of the polymers were determined via NMR spectroscopy (Table 1). $P(3 M 2 P):{ }^{1} \mathrm{H}$ NMR $\left(300 \mathrm{MHz}, \mathrm{D}_{2} \mathrm{O}-\mathrm{d}_{2}\right) \delta$ : $3.4-3.3$ (broad), $2.4-1.3$ (broad). 

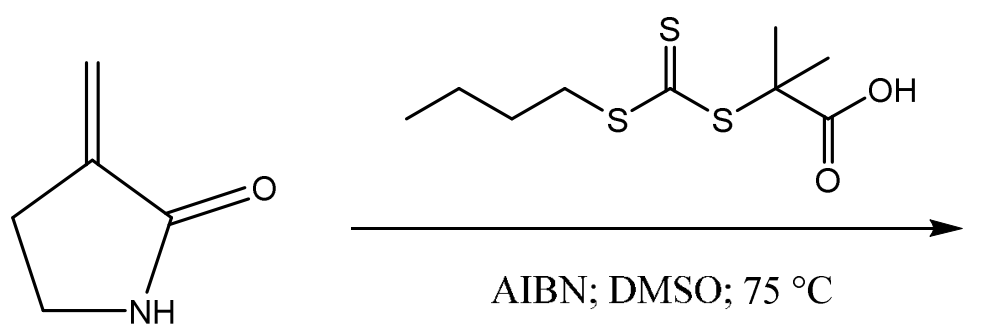

AIBN; DMSO; $75^{\circ} \mathrm{C}$

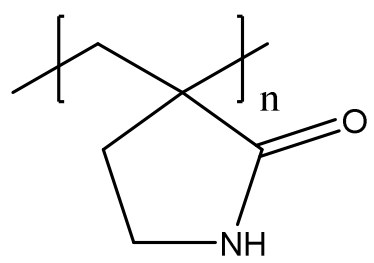

Figure 2. RAFT polymerization of 3M2P.

Table 1. Polymer samples synthesized.

\begin{tabular}{cc}
\hline Polymer & $\begin{array}{c}\boldsymbol{M}_{\boldsymbol{n}} \text { [g/mole] } \\
\left({ }^{\mathbf{1}} \mathbf{H} \text { NMR }\right)\end{array}$ \\
\hline $\mathrm{P}(3 \mathrm{M} 2 \mathrm{P})-1$ & 5500 \\
$\mathrm{P}(3 \mathrm{M} 2 \mathrm{P})-2$ & 2500 \\
\hline
\end{tabular}

\section{Cloud Point Temperature $\left(T_{C l}\right)$ Measurement}

An increase in temperature of the polymer solution causes a phase separation, which can be observed as a cloud or fog appearing in the solution. If the temperature increases, the polymer can eventually precipitate out of solution. The temperature at the first sign of cloudiness gives the cloud point temperature $\left(T_{C l}\right)$. The $T_{C l}$ was measured by heating the sample approximately $2{ }^{\circ} \mathrm{C} / \mathrm{min}$ and closely observing phase changes throughout the measurement. The sample was cooled well below the $T_{C l}$ and the test was repeated for reproducibility. ${ }^{26,27}$

\section{High Pressure Rocker Rig Tests with Synthetic Natural Gas}

The procedure used for the KHI tests is the same as done in previous work by our group, using two steel cell rocker rigs, both supplied by PSL Systemtechnik, Germany. ${ }^{28,}{ }^{29}$ One of the rigs is located in the laboratories at the University of Stavanger (UiS) and one at the Technical University of Denmark (DTU). All the steel cells on both rigs are new and made of 
Swagelok high pressure fittings. They are very similar to the original cells used by our group in past work, but are easier to tighten and therefore less prone to leakages. The volume for each cell is approximately $40 \mathrm{~mL}$, where $20 \mathrm{~mL}$ of an aqueous sample is added per cell for a test. In addition to the rocking, a steel ball is placed in each cell to agitate the test liquid. The loaded cells are then pressurized with a synthetic natural gas (SNG) mixture that will theoretically form the structure II (SII) hydrate as the most stable hydrate. The components of the SNG mixtures used for these tests are listed in Table 2. For the pressure used in these tests (76 bar), the equilibrium temperature $\left(T_{e q}\right)$ has previously been reported to be $20.2{ }^{\circ} \mathrm{C} \pm 0.05$ ${ }^{\circ} \mathrm{C}$. ${ }^{30-32}$ This value is similar to $20.5{ }^{\circ} \mathrm{C}$, which is the calculated value at 76 bar using PVTSim from Calsep. The two gases are very similar and give very similar equilibrium curves. Most of the KHI tests were carried out in the one rig (DTU) during an external research stay by the first author. The $\mathrm{P}(3 \mathrm{M} 2 \mathrm{P})-2$ with and without BGE was tested with the SNG 2 mixture (UiS).

Table 2. Synthetic natural gas (SNG) mixtures used in the KHI performance tests.

\begin{tabular}{ccc}
\hline \multirow{2}{*}{ Component } & \multicolumn{2}{c}{ mole \% } \\
\cline { 2 - 3 } & SNG 1 & SNG 2 \\
\hline Methane & 79.03 & 80.67 \\
Ethane & 10.20 & 10.20 \\
Propane & 5.53 & 4.90 \\
iso-butane & 1.20 & 1.53 \\
$n$-butane & 2.49 & 0.76 \\
$\mathrm{~N}_{2}$ & 0.30 & 0.10 \\
$\mathrm{CO}_{2}$ & 1.24 & 1.84 \\
\hline
\end{tabular}


The constant cooling KHI test procedure was as follows:

1. The additives were dissolved in distilled water and diluted to desired concentration at least one day before testing.

2. $20 \mathrm{~mL}$ sample was added to each cell at $20.5^{\circ} \mathrm{C}$.

3. $3-5$ bars SNG mixture was used to purge the cells after applying vacuum. This was done to remove the air from the system. After depressurizing the system, vacuum was applied once more before pressurizing to approximately 76 bars.

4. The constant cooling parameters were set to a rocking rate of 20 rocks per minute, rocking angle of $40^{\circ}$ and an approximate cooling rate of $1{ }^{\circ} \mathrm{C} /$ hour from $20.5^{\circ} \mathrm{C}$ to 2 ${ }^{\circ} \mathrm{C}$.

5. Data logging for each cell on a local computer is possible for both pressure and temperature, as there are sensors connected to each test cell. In addition, there is also a temperature sensor in the cooling bath.

From the pressure and temperature data, we can generate a pressure and temperature graph for each cell as shown in Figures 3 and 4. These are typical plots generated after a constant cooling program. Figure 3 shows a summary chart of all the cells. Here only four cells are used. Figure 4 shows the result of a single cell. As seen from these figures, the pressure in the beginning of the test will decrease by as much as two bars as the gas dissolves in the aqueous phase during initial rocking. Since it is a closed system, the pressure will decrease with a constant rate as the temperature also decreases from $20.5{ }^{\circ} \mathrm{C}$ to $2.0{ }^{\circ} \mathrm{C}$. The experiment finishes after about 1230 minutes at which point the cells are warmed to $25^{\circ} \mathrm{C}$ (i.e. well outside the hydrate stability region), depressurized, cleaned and made ready for a new experiment. 


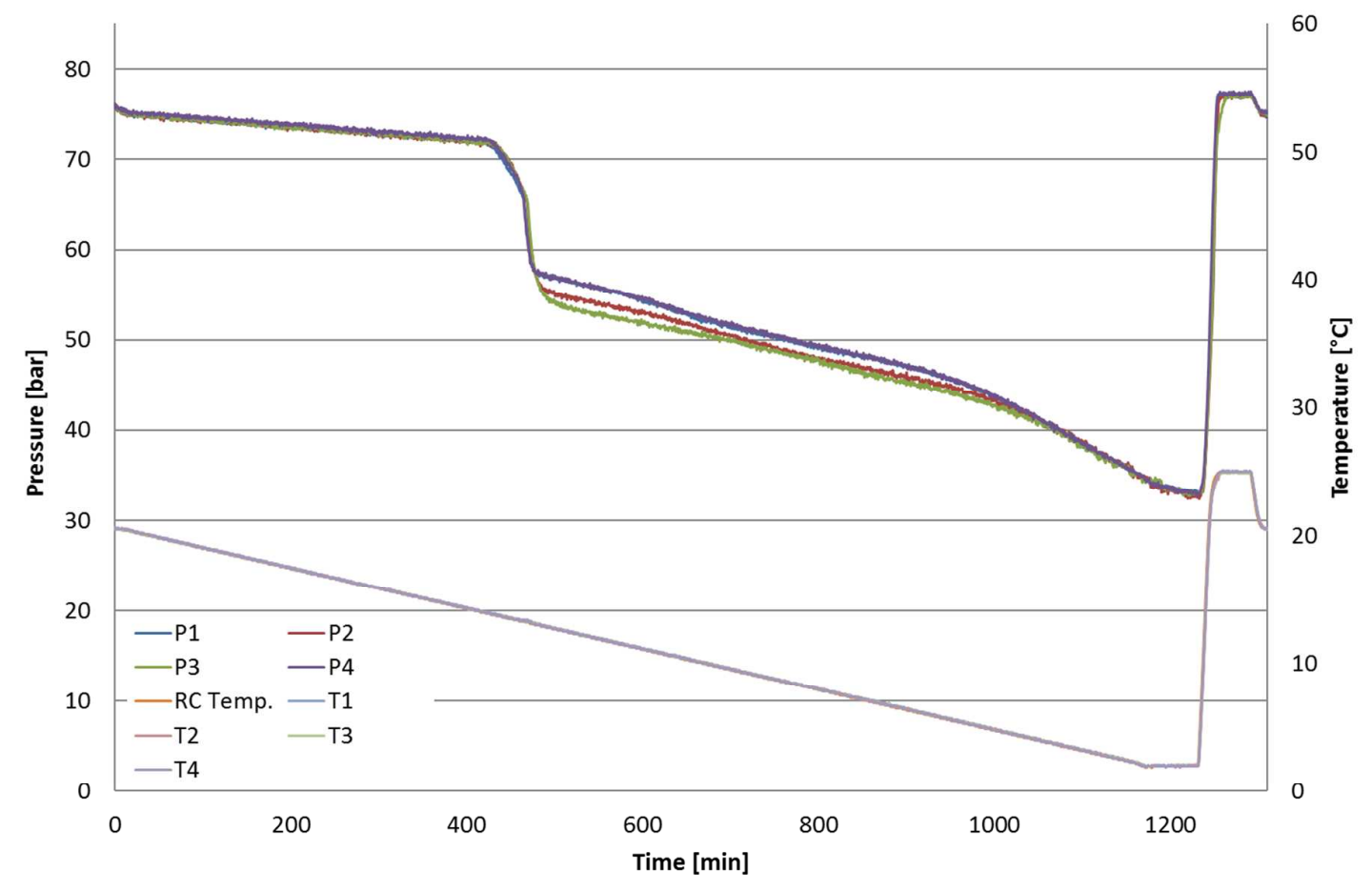

Figure 3. Summary of the results from a constant cooling test with 4 cells.

Figure 4 shows an example of a plot generated for one of the cells, here the data for cell 1 from Figure 3 is shown. P1 shows the pressure and T1 shows the temperature at any given time for cell 1 during the experiment. The hydrate onset temperature $\left(T_{o}\right)$ is the most relevant result, as it indicates the temperature where macroscopic hydrate formation is first detected (increased pressure drop). $T_{o}$, as shown in Figure 4, is found after approximately 422 minutes at a temperature of $14.0^{\circ} \mathrm{C}$ and $T_{a}$, which is the rapid growth temperature, is found after approximately 466 minutes at a temperature of $13.4{ }^{\circ} \mathrm{C}$. The nucleation process is not visible in these graphs and may have started some time before the first pressure drop due to hydrate formation. $T_{a}$ is the temperature for rapid hydrate formation. The difference in $T_{o}$ and $T_{a}$ can give an indication of the KHIs ability to delay the rapid hydrate formation. 


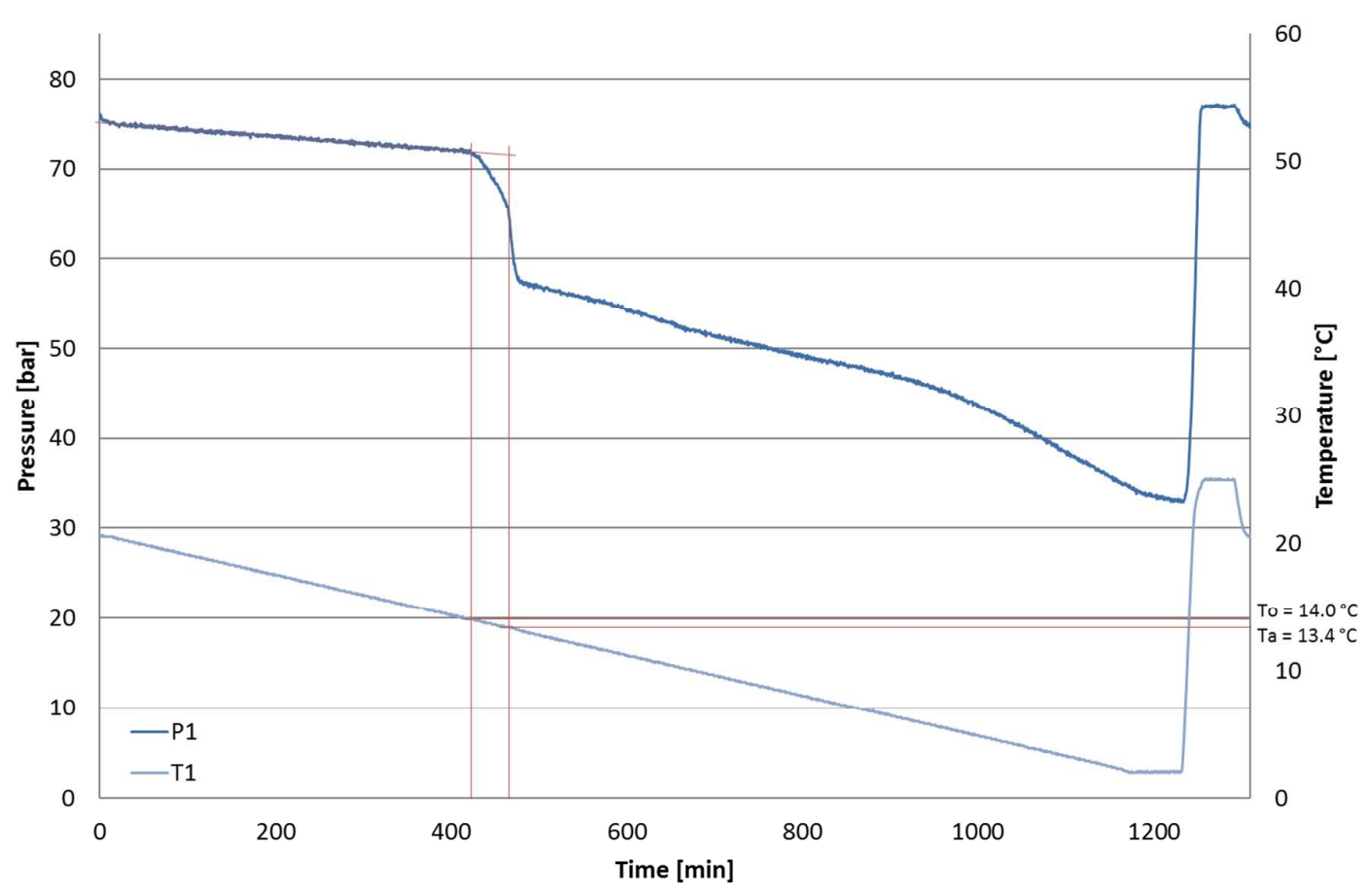

Figure 4. Determination of $T_{o}$ and $T_{a}$ from cell 1 after a constant cooling test.

When using the standard constant cooling test method for screening of KHIs, usually 8-10 experiments are carried out for each polymer to obtain better statistical information. In general, for the results in this paper, we observe a maximum scattering of $15-25 \%$ in the $T_{o}$ data points. This observed maximum percentage may be higher than reported before in our group, possibly due to the use of new rocking cells. The cells were run for a few weeks prior to carrying out this study. However we still observed somewhat larger scattering. The scattering reflects the stochastic nature of hydrate nucleation. However, as the new cells are used even more, the scattering will also be reduced. ${ }^{29}$ Another reason for the higher scattering in $T_{o}$ values is the mediocre performance of the $\mathrm{P}(3 \mathrm{M} 2 \mathrm{P})$, an effect which has often been observed previously for KHIs with mediocre performance in our research. No systematic error was observed in any of the cells, i.e. none of the cells showed consistently better or worse 
results for each experiment. All of the samples used are either fresh or heated well above the equilibrium temperature so there are no residual hydrates in the system at test start.

\section{RESULTS AND DISCUSSION}

\section{KHI performance comparison of different concentrations with and without a synergist.}

Table 3 lists the results from the KHI tests in addition to the cloud point values. Figure 5 shows the average $T_{o}$ and $T_{a}$ values of the different concentrations of all the polymers tested. Results with two known KHI polymers, PVP, $M_{w}=8000-9000 \mathrm{~g} / \mathrm{mole}$ and PVCap, $M_{w}=$ 7000-12000 g/mole, are also added for comparison. In addition, PVP was also tested at 2500 ppm on both rocker rigs as a reference. For the lower molecular weight sample, $\mathrm{P}(3 \mathrm{M} 2 \mathrm{P})-2$, only 4 tests with a concentration of $2500 \mathrm{ppm}$ and 3 tests with $2500 \mathrm{ppm}$ doped with $1 \mathrm{wt} \%$ BGE were carried out. This is because of the limited amount of polymer available.

Both the 3M2P polymers were initially difficult to dissolve and the solutions were slightly hazy even when refrigerated at $4{ }^{\circ} \mathrm{C}$. Previously, $\mathrm{P}(3 \mathrm{M} 2 \mathrm{P})$ has been reported to exhibit no cloud point in water up to $100{ }^{\circ} \mathrm{C} .{ }^{25}$ We think the haziness of our solutions could be due to the RAFT agent used in the RAFT-mediated polymerization of 3M2P. Since our P(3M2P) is a low molar mass polymer, the RAFT's $\omega$ Z-endgroup, which is a $n$-butyl moiety, could possibly be influencing aqueous solubility. 
Table 3. Constant cooling KHI tests, average of 10 tests unless otherwise stated.

\begin{tabular}{ccccccccc}
\hline & $\begin{array}{c}\text { Synergist } \\
\text { Chemical }\end{array}$ & \multicolumn{2}{c}{$\mathbf{2 5 0 0} \mathbf{~ p p m}$} & \multicolumn{2}{c}{$\mathbf{5 0 0 0} \mathbf{~ p p m}$} & \multicolumn{2}{c}{$\mathbf{7 5 0 0} \mathbf{~ p p m}$} \\
\cline { 2 - 9 } & $\mathbf{B G E}$ & $\boldsymbol{T}_{\boldsymbol{o}} /{ }^{\circ} \mathbf{C}$ & $\boldsymbol{T}_{\boldsymbol{a}} /{ }^{\circ} \mathbf{C}$ & $\boldsymbol{T}_{\boldsymbol{o}} /{ }^{\circ} \mathbf{C}$ & $\boldsymbol{T}_{\boldsymbol{a}} /{ }^{\circ} \mathbf{C}$ & $\boldsymbol{T}_{\boldsymbol{o}} /{ }^{\circ} \mathbf{C}$ & $\boldsymbol{T}_{\boldsymbol{a}} /{ }^{\circ} \mathbf{C}$ & $\boldsymbol{T}_{\boldsymbol{C}} /{ }^{\circ} \mathbf{C}$ \\
\hline No additive & & 17.2 & 16.4 & & & & & \\
PVCap & & 9.9 & 8.2 & 7.3 & 6.4 & 5.6 & 5.1 & 31 \\
PVP & & $13.8^{\mathrm{c}}$ & $10.3^{\mathrm{c}}$ & & & & & \\
PVP & & 13.6 & 10.5 & 13.7 & 10.3 & 10.5 & 8.9 & $>95$ \\
PVP & 10000 & 13.3 & 12.6 & 12.4 & 11.8 & 11 & 10.4 & $>95$ \\
P(3M2P)-1 & & 15.5 & 15.3 & 15.2 & 15 & 14.8 & 14.6 & $*$ \\
P(3M2P)-1 & 10000 & 14.1 & 13.4 & 14.3 & 13.5 & 14.4 & 13.5 & $*$ \\
P(3M2P)-2 & & $15.5^{\mathrm{a}, \mathrm{c}}$ & $15.3^{\mathrm{a}, \mathrm{c}}$ & & & & & $*$ \\
P(3M2P)-2 & 10000 & $15.4^{\mathrm{b}, \mathrm{c}}$ & $14.3^{\mathrm{b}, \mathrm{c}}$ & & & & & $*$ \\
\hline
\end{tabular}

${ }^{\mathrm{a}} 4$ tests, ${ }^{\mathrm{b}} 3$ tests, ${ }^{\mathrm{c}}$ result from UiS rocker rig

*Solutions cloudy down to at $4{ }^{\circ} \mathrm{C}$, except P(3M2P)-2 with added BGE.

PVCap is a well-known KHI that delays hydrate nucleation and crystal growth. As seen from the results, PVCap is the best performing KHI of the polymers tested here. Increasing concentration gives increasing performance.

At the lower concentrations, $\mathrm{P}(3 \mathrm{M} 2 \mathrm{P})-1$ and $\mathrm{P}(3 \mathrm{M} 2 \mathrm{P})-2\left(M_{n}=2500-5500 \mathrm{~g} / \mathrm{mole}\right)$ perform quite similar to PVP $\left(M_{w}=8000-9000 \mathrm{~g} / \mathrm{mole}\right)$. However, PVP outperforms $\mathrm{P}(3 \mathrm{M} 2 \mathrm{P})$ at 7500 ppm, with and without BGE. The addition of BGE to the PVP solutions increases the performance at $5000 \mathrm{ppm}$. However this glycol does not really change the performance for the sample containing $2500 \mathrm{ppm}$ or $7500 \mathrm{ppm}$ PVP. Carstensen et al. also reported no significant synergy with PVP and BGE. However this was in a THF hydrate system. ${ }^{33}$ 


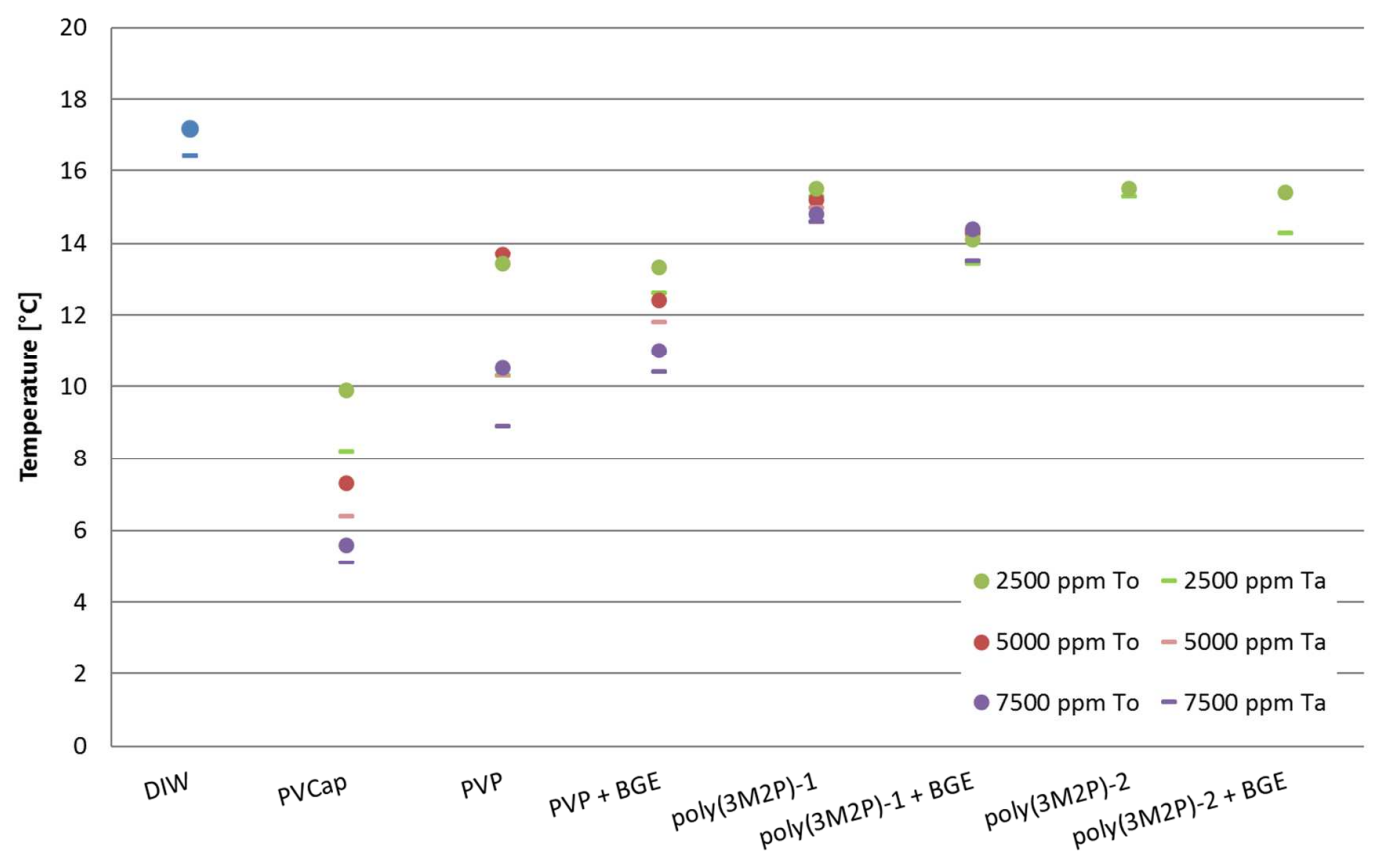

Figure 5. Summary of results found in Table 3.

We carried out t-tests to check for significant difference between two sets of $T_{o}$ or $T_{a}$ values. ${ }^{34}$ The different $\mathrm{P}(3 \mathrm{M} 2 \mathrm{P})-1$ concentrations showed quite similar results over all, where 5000 ppm is not significantly different from either $7500 \mathrm{ppm}$ or $2500 \mathrm{ppm}$. $2500 \mathrm{ppm}$ is significantly different from $7500 \mathrm{ppm}$ with a P-value of less than 0.05 .

There is no statistically significant difference between the $T_{o}$ values of the $\mathrm{P}(3 \mathrm{M} 2 \mathrm{P})-1$ samples without BGE in comparison to the samples with added BGE. Interestingly there is a small but significant difference in these sets of results for the $T_{a}$ values. This suggests that BGE has some synergistic effect, or that BGE in itself has some inhibiting effect on hydrate crystal growth.

We assumed that the structural similarities of $\mathrm{P}(3 \mathrm{M} 2 \mathrm{P})$ to $\mathrm{PVP}$ would give a similar $T_{C l}$ and KHI performance. Both polymers contain a nitrogen atom and a carbonyl group $(\mathrm{C}=\mathrm{O})$ that 
are believed to be a very suitable hydrophilic moiety for the interaction to either free water or the hydrate surface. ${ }^{35-37}$ One possibility for the mediocre performance of $\mathrm{P}(3 \mathrm{M} 2 \mathrm{P})$ can be that the structure of the $\mathrm{P}(3 \mathrm{M} 2 \mathrm{P})$ allows for a possible resonance stabilization of the double bond from the $\mathrm{C}=\mathrm{O}$ group to $\mathrm{C}=\mathrm{N}$, as shown in Figure 6. This is not possible for PVP as the nitrogen atom is tertiary. The resonance stabilization in $\mathrm{P}(3 \mathrm{M} 2 \mathrm{P})$ will energetically lower the bonding preference of the carbonyl group to water molecules compared to PVP.

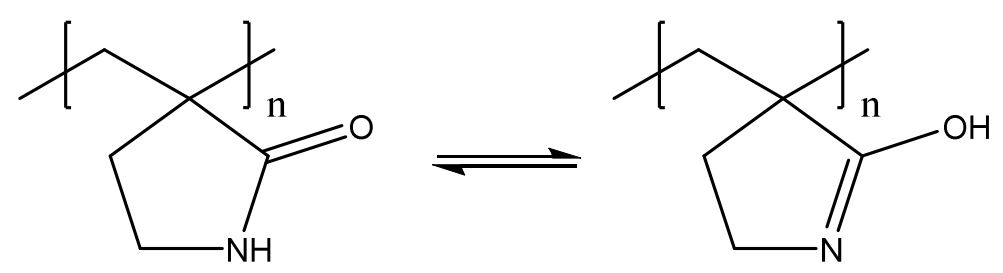

Figure 6. Resonance stabilization of the amide group in $\mathrm{P}(3 \mathrm{M} 2 \mathrm{P})$.

Another explanation is related to the size of the hydrophobic area of the pendant groups in PVP and $\mathrm{P}(3 \mathrm{M} 2 \mathrm{P})$, as shown in Figure 7. The larger pendant hydrophobic groups generally give increasing KHI performance, as long as the polymer is kept water-soluble. ${ }^{31,38,39}$ This can also explain the slightly better performance of PVP, where the lactam group is not a part of the polymer backbone, but bound via the nitrogen.

A third explanation can be that since the lactam group is directly bound to the polymer backbone, this may cause more sterical hindrance for the pendant group. 

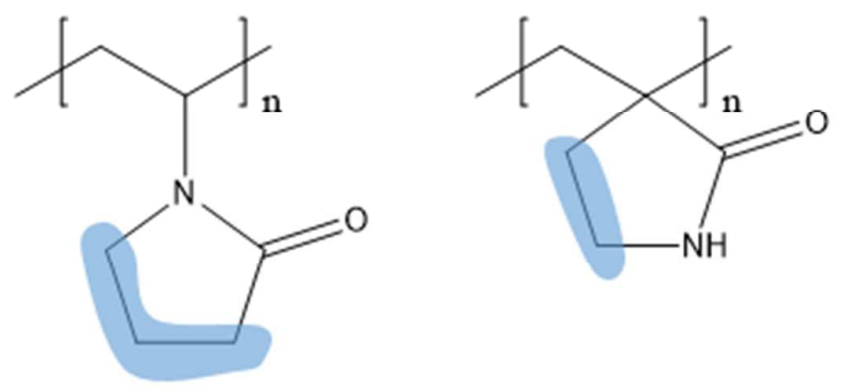

Figure 7. PVP (left), P(3M2P) (right). Blue area indicates hydrophobic part of the pendant groups.

\section{CONCLUSION}

The polymer poly(3-methylene-2-pyrrolidone) ( $\mathrm{P}(3 \mathrm{M} 2 \mathrm{P}))$, closely related to $\mathrm{PVP}$, has been tested for the first time as a KHI. $\mathrm{P}(3 \mathrm{M} 2 \mathrm{P})$ was reported to have a high cloud point $\left(>90^{\circ} \mathrm{C}\right.$ in aqueous solution) which is useful for high temperature injection of KHIs.

High-pressure rocker rigs with an SNG mixture and the constant cooling program was used for the experiments. Two samples of $\mathrm{P}(3 \mathrm{M} 2 \mathrm{P})$ with different molecular weights were tested with and without BGE (1.0 wt\%). In addition, one of the samples was also tested at three different concentrations $(2500,5000$ and $7500 \mathrm{ppm})$ where all concentrations were also doped with BGE (1 wt\%).

BGE was reported as a synergist by $\mathrm{Hu}$ et al. for PVP. ${ }^{22}$ In our hands, we find that there is little or no synergy. For both $\mathrm{P}(3 \mathrm{M} 2 \mathrm{P})-1$ and $\mathrm{P}(3 \mathrm{M} 2 \mathrm{P})-2$, BGE as dopant shows some weak synergy, however no significant difference. This is in agreement with a report from Carstensen et al. who also found no significant synergy with PVP and BGE. ${ }^{33}$

The KHI performance for $\mathrm{P}(3 \mathrm{M} 2 \mathrm{P})$ reported in this paper can be explained by a possible resonance stabilization of the double bond from the oxygen to the nitrogen, which is not 
possible for PVP. In addition to this phenomenon, the hydrophobic moiety of $\mathrm{P}(3 \mathrm{M} 2 \mathrm{P})$ is smaller than that of the hydrophobic pendant moiety of PVP. This can also affect the KHI performance and has been observed before for other KHIs, i.e. with increasing hydrophobicity, KHI performance increases, provided that aqueous solubility is maintained.

We hope to investigate variations on $\mathrm{P}(3 \mathrm{M} 2 \mathrm{P})$ with larger, more hydrophobic rings, as well as copolymers with more hydrophobic monomers and possibly also other synergists in order to improve the performance of this new class of polymer.

\section{ACKNOWLEDGEMENTS}

BK, IH and RP acknowledge support by the South African Research Chairs Initiative of the Department of Science and Technology (DST) and National Research Foundation (NRF) of South Africa (Grant No 46855).

\section{REFERENCES}

1. Kelland, M. A., Production chemicals for the oil and gas industry. 2nd ed. ed.; CRC Press: Boca Raton, Fla, 2014.

2. Sloan, E. D.; Koh, C. A., Clathrate hydrates of natural gases. 3rd ed. ed.; CRC Press: Boca Raton, Fla, 2008; Vol. 119.

3. Sloan, E. D., Natural gas hydrates in flow assurance. Elsevier Gulf Professional Publ.: Amsterdam, 2011.

4. Schicks, J. M.; Naumann, R.; Erzinger, J.; Hester, K. C.; Koh, C. A.; Sloan, E. D., Phase Transitions in Mixed Gas Hydrates: Experimental Observations versus Calculated Data. The Journal of Physical Chemistry B 2006, 110, (23), 11468-11474. 
5. Ohno, H.; Moudrakovski, I.; Gordienko, R.; Ripmeester, J.; Walker, V. K., Structures of Hydrocarbon Hydrates during Formation with and without Inhibitors. The Journal of Physical Chemistry A 2012, 116, (5), 1337-1343.

6. Walsh, M. R.; Koh, C. A.; Sloan, E. D.; Sum, A. K.; Wu, D. T., Microsecond Simulations of Spontaneous Methane Hydrate Nucleation and Growth. Science 2009, 326, (5956), 1095-1098.

7. Frostman, L. M.; Thieu, V.; Crosby, D. L.; Downs, H. H., Low-Dosage Hydrate Inhibitors (LDHIs): Reducing Costs in Existing Systems and Designing for the Future. In Society of Petroleum Engineers.

8. Clark, L. W.; Anderson, J.; Crosby, D.; Frostman, L.; Poynton, N.; Thieu, V., LDHI Opportunities For Offshore Mediterranean Production. In Offshore Mediterranean Conference.

9. Perrin, A.; Goodwin, M. J.; Musa, O. M.; Berry, D. J.; Corner, P.; Edkins, K.; Yufit, D. S.; Steed, J. W., Hydration Behavior of Polylactam Clathrate Hydrate Inhibitors and Their Small-Molecule Model Compounds. Crystal Growth \& Design 2017, 17, (6), 3236-3249.

10. Storr, M. T.; Taylor, P. C.; Monfort, J.-P.; Rodger, P. M., Kinetic Inhibitor of Hydrate Crystallization. Journal of the American Chemical Society 2004, 126, (5), 1569-1576.

11. Yang, J.; Tohidi, B., Characterization of inhibition mechanisms of kinetic hydrate inhibitors using ultrasonic test technique. Chemical Engineering Science 2011, 66, (3), 278283.

12. Cohen, J. M.; Wolf, P. F.; Young, W. D., Enhanced Hydrate Inhibitors: Powerful Synergism with Glycol Ethers. Energy \& Fuels 1998, 12, (2), 216-218.

13. Kelland, M. A.; Moi, N.; Howarth, M., Breakthrough in Synergists for Kinetic Hydrate Inhibitor Polymers, Hexaalkylguanidinium Salts: Tetrahydrofuran Hydrate Crystal 
Growth Inhibition and Synergism with Polyvinylcaprolactam. Energy \& Fuels 2013, 27, (2), 711-716.

14. Sloan, E. D., Method for controlling clathrate hydrates in fluid systems. In Google Patents: 1995.

15. Anselme, M. J.; Reijnhout, M. J.; Muijs, H. M.; Klomp, U. C., A method for inhibiting gas hydrate formation. In Google Patents: 1993.

16. Kelland, M. A.; Svartaas, T. M.; Dybvik, L., A New Generation of Gas Hydrate Inhibitors. In Society of Petroleum Engineers.

17. Kelland, M. A.; Grinrød, A.; Milanovic, J., Benchtop Euler wheel for kinetic hydrate inhibitor screening: Comparison to Rocking cells. Energy \& Fuels submitted aug. 2017.

18. Cohen, J. M.; Wolf, P. F.; Young, W. D., Method for preventing or retarding the formation of gas hydrates. In Google Patents: 1998.

19. Sohn, Y. H.; Seo, Y., Effect of monoethylene glycol and kinetic hydrate inhibitor on hydrate blockage formation during cold restart operation. Chemical Engineering Science 2017, 168, 444-455.

20. Klomp, U.; Mehta, A. In Validation of Kinetic Inhibitors for Sour Gas Fields, IPTC 2007: International Petroleum Technology Conference, 2007; 2007.

21. Fu, B., The development of advanced kinetic hydrate inhibitors. In Chemistry in the Oil Industry VII: Performance in a Challenging Environment, Balson, T.; Craddock, H. A.; Dunlop, J.; Frampton, H.; Payne, G.; Reid, P., Eds. The Royal Society of Chemistry: 2002; pp 264-276.

22. Hu, J.; Wang, Y.; Lang, X.; Du, J.; Li, Q.; Fan, S., Synthesis and application of a novel combined kinetic hydrate inhibitor. Science China Technological Sciences 2011, 54, (12), 3289-3295. 
23. Sefidroodi, H.; Cheng Chua, P.; Kelland, M. A., THF hydrate crystal growth inhibition with small anionic organic compounds and their synergistic properties with the kinetic hydrate inhibitor poly(N-vinylcaprolactam). Chemical Engineering Science 2011, 66, (10), 2050-2056.

24. Heyns, I. M.; Pfukwa, R.; Klumperman, B., Synthesis, Characterization, and Evaluation of Cytotoxicity of Poly(3-methylene-2-pyrrolidone). Biomacromolecules 2016, 17, (5), 1795-1800.

25. Ueda, M.; Takahashi, M.; Suzuki, T.; Imai, Y.; Pittman, C. U., Polymerization of $\alpha-$ methylene-N-methylpyrrolidone. Journal of Polymer Science: Polymer Chemistry Edition 1983, 21, (4), 1139-1149.

26. Sekikawa, H.; Hori, R.; Arita, T.; Ito, K.; Nakano, M., Application of the Cloud Point Method to the Study of the Interaction of Polyvinylpyrrolidone with Some Organic Compounds in Aqueous Solution. Chemical \& Pharmaceutical Bulletin 1978, 26, (8), 24892496.

27. Kelland, M. A.; Abrahamsen, E.; Ajiro, H.; Akashi, M., Kinetic Hydrate Inhibition with N-Alkyl-N-vinylformamide Polymers: Comparison of Polymers to n-Propyl and Isopropyl Groups. Energy \& Fuels 2015, 29, (8), 4941-4946.

28. Chua, P. C.; Kelland, M. A., Tetra(iso-hexyl)ammonium Bromide-The Most Powerful Quaternary Ammonium-Based Tetrahydrofuran Crystal Growth Inhibitor and Synergist with Polyvinylcaprolactam Kinetic Gas Hydrate Inhibitor. Energy \& Fuels 2012, $26,(2), 1160-1168$.

29. Lone, A.; Kelland, M. A., Exploring Kinetic Hydrate Inhibitor Test Methods and Conditions Using a Multicell Steel Rocker Rig. Energy \& Fuels 2013, 27, (5), 2536-2547. 30. Mady, M. F.; Kelland, M. A., Tris(tert-heptyl)-N-alkyl-1-ammonium bromidesPowerful THF hydrate crystal growth inhibitors and their synergism with poly- 
vinylcaprolactam kinetic gas hydrate inhibitor. Chemical Engineering Science 2016, 144, 275-282.

31. Chua, P. C.; Kelland, M. A., Poly(N-vinyl azacyclooctanone): A More Powerful Structure II Kinetic Hydrate Inhibitor than Poly(N-vinyl caprolactam). Energy \& Fuels 2012, $26,(7), 4481-4485$.

32. Kelland, M. A.; Reyes, F. T.; Trovik, K. W., Tris(dialkylamino)cyclopropenium chlorides: Tetrahydrofuran hydrate crystal growth inhibition and synergism with polyvinylcaprolactam as gas hydrate kinetic inhibitor. Chemical Engineering Science 2013, 93, 423-428.

33. Carstensen, A.; Creek Jefferson, L.; Koh Carolyn, A., Investigating the performance of clathrate hydrate inhibitors using in situ Raman spectroscopy and differential scanning calorimetry. In American Mineralogist, 2004; Vol. 89, p 1215.

34. Walpole, R. E., Probability \& statistics for engineers \& scientists. 9th ed. ed.; Pearson: Boston, Mass, 2012.

35. Kelland, M.; Wytherst, M., A review of kinetic hydrate inhibitors: Tailor-made watersoluble polymers for oil and gas industry applications. In Nova Science Publishers, Inc.: New York: 2011; Vol. 8.

36. Lederhos, J. P.; Long, J. P.; Sum, A.; Christiansen, R. L.; Sloan Jr, E. D., Effective kinetic inhibitors for natural gas hydrates. Chemical Engineering Science 1996, 51, (8), 1221 1229.

37. Moon, C.; Hawtin, R. W.; Rodger, P. M., Nucleation and control of clathrate hydrates: insights from simulation. Faraday Discussions 2007, 136, (0), 367-382.

38. Abrahamsen, E.; Kelland, M. A., Carbamate Polymers as Kinetic Hydrate Inhibitors. Energy \& Fuels 2016, 30, (10), 8134-8140. 
39. O’Reilly, R.; Ieong, N. S.; Chua, P. C.; Kelland, M. A., Missing Poly(N-vinyl lactam)

Kinetic Hydrate Inhibitor: High-Pressure Kinetic Hydrate Inhibition of Structure II Gas

Hydrates with Poly(N-vinyl piperidone) and Other Poly(N-vinyl lactam) Homopolymers.

Energy \& Fuels 2011, 25, (10), 4595-4599. 